\title{
Gender Perspective in Assessing Productivity, Quality, and Innovation as Sustainability Factors In Embroidery Business in Tasikmalaya, West Java
}

\author{
Rodhiah $^{1}$ and Kartika Nuringsih ${ }^{2}$ \\ \{rodhiah@fe.untar.ac.id ${ }^{1}$ \} \\ ${ }^{1,2}$ Faculty of Economics, Tarumanagara University Jakarta, Indonesia
}

\begin{abstract}
Along with the development of creative economy, the Tasik embroidery business has the potential to be empowered as a regional superior. The study is viewed from the aspects of raw materials, investment in computer machines, the availability of bank cooperation and assistance from Cooperatives, Industry and Trade Department (KOPERINDAG). In Tasikmalaya, this sector is able to produce performance. From the demand side, apparel or fashion products are increasing. To maintain the sustainability of the embroidery business, three aspects are examined: Productivity, Quality, and Innovation. These three aspects are perceived by embroidery craftsmen gender perspective (female vs male craftsmen), The purpose of the research is to identify the differences in craftsman perceptions of items that represent three aspects of performance appraisal, namely: productivity, quality, and innovation based on the three profiles of the above craftsmen.To examine these differences, three hypotheses were formulated. Data collection method was carried out through distributing questionnaires. The data collection process was carried out in the central embroidery industry in Tasikmalaya and Pasar Tasik Pasar Abang. Reliability and validity testing was done to test the suitability and feasibility of each item in the process of instrumentation in the aspects of productivity, quality, and innovation. Then the difference test was carried out with an analysis tool using KruskalWallis non parametric statistics. The results showed that all research hypotheses were not rejected. It means there is no difference of opinion from the gender in assessing aspects of productivity, quality, and innovation. So that the results of the study can become information for Koperindag Office in Tasikmalaya especially in the process of mentoring embroidery craftsmen. The assistance is related to the provision of training, credit, exhibition, or other cooperation facilities.
\end{abstract}

Keywords: Embroidery sectors, Productivity, Quality, Innovation, gender

\section{Introduction}

The embroidery industry is a leading sector in Tasikmalaya regency, so this community has the potential to be empowered by the Tasikmalaya Regional Government. Through mapping,four potential handicraft businesses in Tasikmalaya were identified: pandanus, mendong, bamboo, and embroidery (Rodhiah \& Kartika N, 2014). Of the many embroidery industries there are two industrial centers, namely: Kawalu and Cikatomas.

By time, the performance of the embroidery sector has been increasingly proving to meet the needs of clothing in Indonesia so that the focus of this study is on business performance.(Chen, 2011), (Rivai, 2011) said that performance is an overall success rate during a certain period in carrying out tasks. (Pardosi1, Tambunan, \& Syahputri, 2013) measured $360^{\circ}$ based employee performance, while (Kaur; 2013), and (Ghutke, Jaiswal, \& Thakur, 2014) emphasized personality characteric perspective, job competency, and general 
attitude. (Hudson, Smart, \& Bourne, 2001) (Rao, 2008) identified six categories of performance of SMEs to be the focus of assessment, namely: quality, time, flexibility, finance, customer satisfaction, human resources appraisal performance with $360^{\circ}$ feedbacks.(Kaur, 2013), Ghutke et.al; 2014). used stakeholders and financial, customers, internal process, growth, and innovation perspectives.

Considering the development of the above assessment, research development was carried out with a focus on identifying perceptions of aspects of productivity, quality, and innovation (Kristiyanti, 2016) as part of the supporting factors for the success of the embroidery business in Tasikmalaya. The flow of the study emphasized on the gender difference of craftsmen. The gender difference will be examined in assessing various items related to Productivity, Quality, and Innovation. Thus the title of the research is: Gender Perspective in Assessing "Productivity, Quality, and Innovation".

The problems in this study are:

1. Are there differences from gender perspectives in assessing productivity aspects on the sustainability of embroidery business performance?

2. Are there differences from gender perspectives in assessing quality aspects on the sustainability of embroidery business performance?

3. Are there differences form gender perspectives in assessing aspects of innovation in the sustainability of embroidery business performance?

\section{Literatur Riview}

\section{a. Hypothesis Formation}

Related to productivity aspects referring to (Summers, n.d.), the measurement of company performance depends on labor productivity so that one aspect to assess the sustainability of embroidery business performance is reviewed through these aspects. Basically, the level of differences in respondents' perceptions will be analyzed in assessing employee productivity. Then still referring to (Summers, n.d.), (Hudson et al., 2001) identified the performance categories of SMEs caused by quality management. Furthermore, if it refers to the entrepreneurship approach, then one of the main factors is innovation, so that success in innovating will affect the success of the entrepreneur (Bianchi, 2012)

The three aspects were divided into several indicators, then the significance of the differences was analyzed from the perceptions of the embroidery craftsmen. This perception would differentiate the respondent's gender perspective of the craftsman. Based on these developments, the linkages between aspects of performance appraisal and profiles of embroidery craftsmen in Tasikmalaya were summarized in the framework of thought below: 




Referring to the framework above, the hypotheses were developed as follows:

H1: There are differences in gender perspectives in assessing productivity aspects on the sustainability of embroidery business performance.

$\mathrm{H} 2$ : There are differences in gender perspectives in assessing quality aspects in the sustainability of embroidery business performance.

H3: There are differences in gender perspectives in assessing aspects of innovation in the sustainability of embroidery business performance.

\section{Research Methods}

The study was conducted from March to July 2018. The locations or places of research were at the central embroidery of Kawalu and several other sub-districts which had a centralized embroidery business in Tasikmalaya regency, West Java, including Sukaraja, Karangnunggal, Cikatomas, and Pancatengah. In addition, the process of extracting information was done at Pasar Tasik Pasar Abang on Mondays and Thursdays due to Tasik craftsmen and traders selling schedule at the central wholesaler.

The population of this research is embroidery craftsmen consisting of embroidery entrepreneurs in Tasikmalaya regency. The sample selection technique used random sampling from embroidery craftsmen in the above locations. The embroidery entrepreneurs mostly market products in the form of mukena, koko clothes, robe clothes, Pakistani clothes and similar products at Tanah Abang market and Tasik Thamrin City market. The majority of craftsmen used computerized embroidery machines so that they can handle mass production. Most of them started the business by understanding and learning process to support the success of an embroidery entrepreneur.

\section{Operational Variable Research}

Performance measures are divided into several indicators, which are: consistency, comparability, clarity, controllability, contingency, comprehensiveness, boundedness, relevance, and feasibility. (Palmer; 1995 in (Pardosil et al., 2013))(Oesman, 2012),(Puspitasari, Prastawa, \& Diana, 2012). The SMART System Model designed by Wang Laboratory focuses on financial perspectives, market size, productivity, flexibility, customers, costs, processing time, delivery, and quality. Other indicators emphasize financial perspectives, productivity, quality, service, innovation, and personnel(Kristiyanti, 2016). 
The productivity aspect includes various activities related to production capabilities, with measurement items based on the following 6 indicators:

P1: the number of outputs per work hour per employee (Labor usage rate)

P2: the amount of output per unit of raw material (Standard usage rate)

P3: the level of reduction or increase in defective or damaged products (defect rate)

P4: the added value of each employee's total working hours

P5: idle time from the total effective working hours of employees

P6: the total amount of time to produce one product unit

Quality aspects include various activities related to the ability to manage product quality, with measurement items based on the following 4 indicators:

$\mathrm{K} 1$ : the percentage of failed products that occurs every year

$\mathrm{K} 2$ : the amount of costs to replace or repair defective products

$\mathrm{K} 3$ : the amount of costs to manage quality (quality cost) per year

K4: customer ratings on product quality

The innovation aspect includes various activities related to the ability to develop new ways or types of embroidery business, with items measurement based on the following 4 indicators:

I.1: the target in the form of the number of new products at any given period

I.2: the planning to make products for new target markets

I.3: the exact time to introduce a new product

I.4: the comparison of innovations carried out by entrepreneurs / other people

As for the profile of embroidery craftsmen, they were grouped according to their gender, either male or Female. The entire instruments (14 statement items) were developed into a questionnaire using a Likert scale with five options. The questionnaire was created or compiled using simple but systematic language to make it easier to be understood by the respondents to avoid ambiguity or confusion in determining the choice of each statement item. The Likert scale identification is as follows:

- Number 1: Never done (TP)

- Number 2: Rarely done (JD)

- Number 3: Sometimes done (KD)

- Number 4: Frequently done (SD)

- Number 5: Always done (SD *)

The study aims to identify differences between the three aspects of embroidery business performance, namely: Productivity, Quality, and Innovation observed from three embroidery craftsmen gender perspectives. The activity is summarized below.

Table 1. Research Method

\begin{tabular}{|c|c|c|c|}
\hline No & Type of activity & Activities & Activity Result \\
\hline 1 & $\begin{array}{l}\text { Designing profiles } \\
\text { of Tasikmalaya } \\
\text { embroidery } \\
\text { craftsmen }\end{array}$ & $\begin{array}{l}\text { Observation, } \\
\text { Interview, } \\
\text { Questionnaire }\end{array}$ & \multirow{2}{*}{$\begin{array}{l}\text { Primary and } \\
\text { secondary data } \\
\text { for the } \\
\text { preparation of } \\
\text { research } \\
\text { instruments } \\
\text { The instrument } \\
\text { is formed with 1- }\end{array}$} \\
\hline 2 & $\begin{array}{l}\text { The preparation of } \\
\text { instruments related } \\
\text { to aspects of } \\
\text { productivity, } \\
\text { quality, and }\end{array}$ & $\begin{array}{l}\text { Expert } \\
\text { judgment and } \\
\text { literacy } \\
\text { development }\end{array}$ & \\
\hline
\end{tabular}




\begin{tabular}{|c|c|c|c|}
\hline No & Type of activity & Activities & Activity Result \\
\hline & $\begin{array}{l}\text { innovation of Tasik } \\
\text { embroidery } \\
\text { craftsmen }\end{array}$ & & 5 Likert scale \\
\hline 3 & $\begin{array}{l}\text { Testing the validity } \\
\text { and reliability of } \\
\text { instruments with } \\
\text { small scale } \\
\text { deployments }\end{array}$ & $\begin{array}{l}\text { Pilot } \\
\text { instrument, } \\
\text { reliability } \\
\text { test, test } \\
\text { validity }\end{array}$ & \\
\hline 4 & $\begin{array}{l}\text { Large-scale } \\
\text { deployment with } \\
\text { emphasis on } \\
\text { Kruskal-Wallis } \\
\text { non parametric } \\
\text { statistics testing }\end{array}$ & $\begin{array}{l}\text { Different test } \\
\text { between each } \\
\text { craftsman } \\
\text { profile }\end{array}$ & $\begin{array}{l}\text { Differences in } \\
\text { each profile in } \\
\text { the perception of } \\
\text { items on aspects } \\
\text { of productivity, } \\
\text { quality, and } \\
\text { innovation }\end{array}$ \\
\hline
\end{tabular}

\section{a. Data Collection Procedure}

The study combines primary and secondary data in which the primary data collection techniques are: (1) field observations and interviews with embroidery entrepreneurs. (2) Expert judgment to evaluate instruments from aspects of productivity, quality, and innovation. (3) Questionnaire pilot with limited questionnaire distribution. (4) Processing of data using Kruskal Wallis followed by analysis of results based on three craftsman profiles, namely: gender perspective, educational background, and craftsman status.

\section{b. Validity and Reliability Testing}

The results of the SPSS output validity and reliability of each statement item is presented in the following table. Based on the results of processing, the value of Cronbach's Alpha is 0.923 from 14 statement items, so that it can be concluded that the instrument is valid for further use. While the reliability test results also show that the entire statement item is in a reliable condition with an indication of the corrected total item correlation above 0.20.

Table 2. Processing Instrument Validity

\begin{tabular}{|c|c|c|c|c|}
\hline & $\begin{array}{l}\text { Scale Mean if } \\
\text { Item Deleted }\end{array}$ & $\begin{array}{l}\text { Scale Variance } \\
\text { if Item Deleted }\end{array}$ & $\begin{array}{l}\text { Corrected } \\
\text { Item-Total } \\
\text { Correlation }\end{array}$ & $\begin{array}{l}\text { Cronbach's } \\
\text { Alpha if } \\
\text { Item Deleted }\end{array}$ \\
\hline $\begin{array}{l}\text { Productivity Aspect } \\
1\end{array}$ & 36.4512 & 42.424 & .677 & .917 \\
\hline $\begin{array}{l}\text { Productivity Aspect } \\
2\end{array}$ & 36.5366 & 38.276 & .877 & .909 \\
\hline $\begin{array}{l}\text { Productivity Aspect } \\
3\end{array}$ & 37.3537 & 44.157 & .330 & .928 \\
\hline $\begin{array}{l}\text { Productivity Aspect } \\
4\end{array}$ & 36.7805 & 45.457 & .466 & .924 \\
\hline $\begin{array}{l}\text { Productivity Aspect } \\
5\end{array}$ & 36.6951 & 46.511 & .246 & .927 \\
\hline
\end{tabular}




\begin{tabular}{|c|c|c|c|c|}
\hline $\begin{array}{l}\text { Productivity Aspect } \\
6\end{array}$ & 36.7073 & 46.234 & .252 & .927 \\
\hline Quality Aspect 1 & 37.4146 & 43.258 & .599 & .920 \\
\hline Quality Aspect 2 & 37.0610 & 39.663 & .783 & .913 \\
\hline Quality Aspect 3 & 37.2927 & 40.852 & .776 & .914 \\
\hline Quality Aspect 4 & 37.6829 & 37.355 & .870 & .909 \\
\hline Innovation Aspect 1 & 37.1341 & 40.118 & .792 & .913 \\
\hline Innovation Aspect 2 & 36.9634 & 33.542 & .877 & .913 \\
\hline Innovation Aspect 3 & 36.6829 & 37.478 & .873 & .909 \\
\hline Innovation Aspect4 & 36.3902 & 41.846 & .656 & .918 \\
\hline
\end{tabular}

Based on the results above, the highest corrected total item correlation is identified at 0.877 in the production aspect 2 item and the lowest value is in the production aspect 5 with a value of 0.246 . Furthermore, the aspects of quality has the highest value of 0.870 and the lowest of 0.599 . The aspect of innovation 2 has the highest value of 0.877 and the lowest value of 0.656 . Based on the three groups,the aspect which are considered to produce better reliability are quality and innovation. While the production aspect indicator has a lower reliability, especially in production aspects, 5 and 6 . However, both of them are still above 0.20 so that the reliability level is still acceptable.

Further was testing the differences between male craftsmen and female craftsmen. The difference analysis tool used the Kruskal-Wallis statistical test which is a non-parametric analysis tool as a procedure for testing samples that are independent. The analysis is used when comparing more than two variables (aspects of productivity, quality, and innovation). In this research the groups that were compared were based on craftmen gender. Because more than one is compared, it is very possible for the number of samples between one group to another to be unequal. The significance level of the Kruskal-Wallis analysis was 5\% so that if each item produced a significant value of less than $5 \%$, it means that there is a difference between the group profile, whereas the opposite means the perception of the profile is the same.

\section{a. Expected Target Results}

Based on the above activities it is expected to be able to identify which items or indicators from the aspects of productivity, quality, and innovation have differences from the perception of male vs female. Thus, this research will only give information on the items that are perceived well by the respondents with emphasis on the gender. The information will be an input for the Koperindag office in adjusting the mentoring process or providing facilities (credit, training, exhibitions, or collaboration) among the three profiles. The suitability will bring craftsmen closer to the needs, abilities, and facilities that will be provided by the service. In addition, it is used as a basis for helping people to become independent embroidery entrepreneurs.

\section{b. Hypothesis Testing Results}

The Kruskal-Wallis test was used to determine the acceptance or rejection of the hypothesis. Testing was based on the gender to analyze the level of difference in perceptions concerning aspects of productivity, quality, and innovation. The testing of differences from each profile is described in details as follows: 
H1: There are differences in gender perspectives in assessing productivity aspects on the sustainability of embroidery business performance.

$\mathrm{H} 2$ : There are differences in gender perspectives in assessing quality aspects in the sustainability of embroidery business performance.

H3: There are differences in gender perspectives in assessing innovation aspects on the sustainability of embroidery business performance.

Based on Table 3, the results of the average difference test based on gender on the three aspects were identified. In terms of number, it appears that male embroidery entrepreneurs are more than women, so there is a difference when determining perceptions of the three aspects of performance appraisal. With a proportion of more male embroidery craftsmen (51 people) it is thought that their opinions are superior compared to the women's opinion (as many as 31 people). Further testing results are presented in Table 3

Tabel 3. Gender

\begin{tabular}{|c|c|c|c|}
\hline \multicolumn{2}{|c|}{ Sex } & Number & Mean Rank \\
\hline \multirow{3}{*}{$\begin{array}{l}\text { Produktivity } \\
\text { Aspect }\end{array}$} & Male & 51 & 54.04 \\
\hline & Female & 31 & 20.87 \\
\hline & Total & 82 & \\
\hline \multirow{3}{*}{ Quality Aspect } & Male & 51 & 55.16 \\
\hline & Female & 31 & 19.03 \\
\hline & Total & 82 & \\
\hline \multirow{3}{*}{$\begin{array}{l}\text { Innovation } \\
\text { Aspect }\end{array}$} & Male & 51 & 56.10 \\
\hline & Female & 31 & 17.48 \\
\hline & Total & 82 & \\
\hline
\end{tabular}

\section{c. Perspective testing}

Table 4. Gender Group Testing

\begin{tabular}{|c|c|c|c|}
\hline & $\begin{array}{l}\text { Productivity } \\
\text { Aspects }\end{array}$ & $\begin{array}{l}\text { Quality } \\
\text { Aspect }\end{array}$ & $\begin{array}{l}\text { Aspect of } \\
\text { Innovation }\end{array}$ \\
\hline Chi-Square & 38.968 & 46.079 & 52.655 \\
\hline$\overline{\mathrm{Df}}$ & 1 & 1 & 1 \\
\hline Asymp. Sig. & .000 & .000 & .000 \\
\hline
\end{tabular}

Referring to Table 4 it is proven that there is a significant difference of $1 \%$. It can be concluded that out of 82 respondents, there were differences in gender perspective in assessing productivity. This means that the male and female embroidery craftsmen have different terms in assessing their productivity as part of the embroidery business performance. Thus the hypothesis (H1) is accepted at the level of $1 \%$.

Furthermore, it was proven that there is a significant $1 \%$ difference in the quality aspect. It can be concluded that out of 82 respondents, there are differences in gender perspective in assessing quality. This means that the male and female embroidery craftsmen have different terms in assessing their quality as part of the embroidery business performance. Thus the hypothesis (H2) is accepted at the level of $1 \%$.

Likewise, the aspect of innovation was proven to have a difference at the level of $1 \%$. Of the 82 respondents, there are differences in gender perspective in assessing innovation. This means that male and female embroidery craftsmen have different requirements in assessing 
innovation as part of the embroidery business performance. Thus the hypothesis $(\mathrm{H} 3)$ is accepted at the level of $1 \%$.

\section{d. Discussion}

Based on test results, it can be concluded that there was a significant difference between the respondents' gender and three aspects of performance appraisal. Referring to the results of previous observations that identified differences in perceptions of assessing performance, the results of this study can be attributed that differences in respondent gender can trigger performance variations, especially aspects of productivity, quality, and innovation. It can also be concluded that male craftsmen have stronger ratings than women with orientation on aspects of innovation, then quality, and finally productivity.

The productivity aspect is the ability to produce optimally with the following indicators: (1) Total output per effective working hour per employee, (2) Total output per unit of raw material, (3) Level of reduction / increase in damaged products, (4) Proportion of added value from total effective working hours, (5) Proportion of idle time from total effective working hours, (6) Total amount of production per unit.

Most respondents focus on the aspect of productivity. Moreover, by computerization, the production time becomes more efficient, the number of outputs is optimal, the need for raw materials and labor becomes more efficient, and idle time is minimized. Rrespondents who are graduates and embroidery entrepreneurs are more focused on this aspect. But to encourage the sustainability of the Tasik embroidery sector, the three aspects must be balanced

Quality aspect includes various activities related to the ability to manage product quality, namely: (1) Percentage of failed products per year, (2) Amount of costs for replacing defective products, (3) Total quality costs, (4) Customer assessment of quality product. This aspect is always the number two choice compared to productivity. Taking into account the purchasing power of consumers at Tanah Abang market, prices are the main factor, so quality management is adjusted to its target market. When linked to the DKI Jakarta government's plan to build Tanah Abang as a strategic area in the trade sector, then the opportunity can be utilized by Tasikmalaya embroidery traders and craftsmen by improving product quality.

The innovation aspect in this context consists of various activities related to the ability to develop new ways or new types of embroidery business. The ability to innovate is formed by the creativity of craftsmen so that they are able to produce products that are relatively different from competitors. Through innovation, a product is commercialized to produce more profits for craftsmen. Innovation aspect consists of (1) Number of new products each period, (2) Percentage of product provision for new markets, (3) Time for new product introduction, (4) Comparison of innovations with other companies. This means that if each profile has the same attention to the 4 items above, then the innovative process for Tasik embroidery products will occur in a comprehensive, dynamic and sustainable manner. Innovation will create uniqueness of each embroidery product so that competitiveness will be higher in the embroidery craft sector in Tasikmalaya. The possibility of hijacking designs on similar products from fellow craftsmen, the existence of competitors from outside Tasikmalaya, and overseas (China) will not nescessarily interfere with the sustainability of the Tasikmalaya embroidery sector.

For this reason, it is necessary to equate perceptions between difference gender of respondents in considering the productivity, quality, and innovation as part of the evaluation of embroidery business performance. As an effort to equalize perceptions, cooperation or regulation is needed form the Regional Government, especially the Koperindag office, the Women's Empowerment office, the creative Industry office in the Tasikmalaya regency or 
city. Mentoring the embroidery craftsmen still needs to be done to have the same perception in assessing productivity, quality, and innovation which are important elements in performance appraisal so that by maintaining high production, innovation, and quality, optimal and sustainable business performance will be gained. Disparities caused by gender, innovative knowledge, or quality management can be minimized through regulations or policies from local governments.

\section{Conclusion}

It can be concluded that there is a significant average difference in assessing aspects of productivity, quality, and innovation. The results of the analysis based on gender show that male craftsmen have stronger ratings than women with orientation on aspects of innovation, then quality, and finally productivity.

\section{Suggestion}

As an effort to equalize perceptions, cooperation or regulation is needed from the Regional government, especially the Koperindag office, the Women's Empowerment office, and the creative Industry office in the Tasikmalaya regency or city.Mentoring the embroidery craftsmen needs to be done to have the same perception in assessing productivity, quality, and innovation. Considering these three aspects are important elements in performance appraisal so that maintaining high production, innovation. and quality, will produce business performance optimally and sustainably. To achieve this process, the Regional government of Tasikmalaya regency and Tasikmalaya city need to be facilitated by: (1) Monitoring and evaluating the results of the implementation of creativity and quality management of Tasik embroidery products. Feedback activities are used to foster and improve quality,(2) Conducting competitions of performance appraisal among embroidery craftsmen with prizes in the form of overseas exhibition opportunities for the winners, (3) Creating champion \& prototyping in superior embroidery products in the central Tasikmalaya embroidery business. Considering that embroidery products are very wide ranging from koko, robe, mukena and so on, so that a superior embroidery business prototype will be an example for entrepreneurs or other people. Disparities caused by factors of gender, innovative knowledge, or quality management can be minimized through local government regulations or policies.

\section{References}

[1] Bianchi, C. (2012). Enhancing performance management and sustainable organizational growth through system-dynamics modelling. In Systemic Management for Intelligent Organizations: Concepts, Models-Based Approaches and Applications. https://doi.org/10.1007/978-3-642-29244-6_8

[2] Chen, D. (2011). Research on Performance Management of Chinese SME. Journal of Business and Management, 6(4), 263-265. https://doi.org/10.5539/ijbm.v6n4p263

[3] Ghutke, S., Jaiswal, R., \& Thakur, A. (2014). Case analysis of 360 degree feedback. Ijaretm.Com. Retrieved from http://www.ijaretm.com/publishpaper/2issue3idp3.pdf

[4] Hudson, M., Smart, A., \& Bourne, M. (2001). Theory and practice in SME performance measurement systems. International Journal of Operations and Production Management, 21(8), 1096-1115. https://doi.org/10.1108/EUM0000000005587

[5] Kaur, S. (2013). 360 degree performance appraisal-benefit \& shortcoming. 
International Journal Emerging Research in Management \& Technology, 2(6 June), 83-88.

[6] Kristiyanti, M. (2016). Peran indikator kinerja dalam mengukur kinerja manajemen. Majalah Ilmiah Informatika, 3(2), 103-123. Retrieved from http://www.unaki.ac.id/ejournal/index.php/majalah-ilmiahinformatika/article/download/79/117

[7] Oesman, T. I. (2012). Perancangan sistem pengukuran kinerja perusahaan dengan metode, $I I$ (November), 195-202.

[8] Pardosi1, J., Tambunan, M. M., \& Syahputri, K. (2013). Pengukuran Kinerja Dengan Menggunakan Integrasi $360^{\circ}$ Feedback Dan AHP. Teknik Industri, 3(2), 1-7.

[9] Puspitasari, N. B., Prastawa, H., \& Diana, A. (2012). Perancangan Sistem Pengukuran Kinerja Dengan Metode Performance Prism ( Studi Kasus Pada Pdam Tirta Moedal Cabang Semarang Tengah ), VII(1), 13-18.

[10] Rao, T. V. (2008). Impact of 360 Degree Feedback: A follow-up Study of four Organizations IMPACT OF 360 DEGREE FEEDBACK :, (January 2008).

[11] Rivai, V. (2011). Performance appraisal: sistem yang tepat untuk menilai kinerja karyawan dan meningkatkan daya saing perusahaan. https://doi.org/10.1021/bi970019n

[12] Rodhiah, \& Kartika N. (2014). Implementation of Sustainability Competitive Advantage Models at the Small Medium Enterprises in Tasikmalaya West Java. Issn, 5(23), 2222-1700. Retrieved from www.iiste.org

[13] Summers, D. C. S. (n.d.). Quality Management Creating and Sustaining Organizational Effectivess (2nd ed.). New Jersey.: Pearson Prentice Hall. Upper Saddle River. 